\title{
The Impact of the Director's Personality on Television Work
}

\author{
Wedad Mohyeldeen Mohammed \\ Media Department, Red sea University, Faculty of Arts Port Sudan, Port Sudan, Sudan
}

Email address:

Wedadmm69@gmail.com

\section{To cite this article:}

Wedad Mohyeldeen Mohammed. The Impact of the Director's Personality on Television Work. American Journal of Information Science and Technology. Vol. 3, No. 2, 2019, pp. 50-54. doi: 10.11648/j.ajist.20190302.13

Received: February 26, 2019; Accepted: May 16, 2019; Published: July 22, 2019

\begin{abstract}
The study aimed at identifying the role of the director in crystallizing aesthetic values and explaining the role he plays and his relationship with the working team in addition to the role he plays in directing television programs in a way that suits all societies. The researcher discusses the effects of television output, method, means and general rules. The researcher tried to shed light on the role of the director and his qualifications and tasks in addition to the elements to influence the viewer. The study was based on descriptive statistical analytical method to provide data on the problem of the study, analysis and scientific interpretation. The study reached several results, the most prominent of which are the following: The work of the director is the basis of the information process and therefore the effort of the team depends on the achievement. The art of directing a self - standing science depends on the personality of the director and type of material produced. The art of directing is considered the spirit of the TV product and the last portal in the media work system. The most important recommended by the researcher:-The director must be comprehensive and briefed on all sections of television work and the importance of the team working with him and his ideas. There must be a separation between television and radio director and journalist to give each director his distinctive characteristic in the field of specialization The Sudanese director should keep pace with the developments in the media and work on the personal industry that he wishes to provide and continue the training and not only the studies he has received.
\end{abstract}

Keywords: Journalist, Specialization, Television, Personality, Characters, Media, Concept

\section{Introduction}

In ancient Greece, the director was often the author and also in England, sometimes the most prominent representative of the band, but the idea of the director born of evolution in the twentieth century. When television professionals began to realize that one person should be relied upon, work can provide the elements of harmony, proportionality and unity, and help everyone in the team get the best out of their The director is that hidden magician from the spectator who possesses all the intricate threads of work. In light of the technological and technological development and the opening up of satellite channels and the competition between them, the process of television output and presentation has become the human touch in the exposure and attract the recipient to watch and interact, increasing the threshold of the director as the dynamo engine to put the technical and productivity of the media material, so we wanted to shed light through that paper on the director And their impact on productive work in television and satellite channels.. In light of the technological and technological development and the opening up of satellite channels and the competition between them, the process of television output and presentation is the human touch in the exposure and attract the recipient to watch and interact. Television output is the executive aspect of the production process, if the production of a program needs to provide certain elements material, human and mechanical. The output as an aspect of this process, is specialized in the use of all these elements and guidance and management of the formulation of the program a certain technical formulation then turn the written text or the idea or subject or event to the form of visual and stereotyped is the process of drafting and technical industry. and on this basis increased the threshold on the output as dynamo engine to put the technical and productivity of the media material, so we wanted to shed light through the paper on the character of the director and its impact on the productive work of television and satellite channels. Helmi Mohamed Ahmed Mohsen Dar Al - Uloum\& Publishing. 
This reference deals with the basic structural elements of the output, which consist of texts, static images, elements of the production process, and the elements that are inherited from traditional publishing.

Multimedia includes images, video clips and animations. Multimedia has been supported by its traditional media position, which has the potential to coexist with the event through audio and video, and through the hybridization between traditional and traditional communication technology, known as direct transport Super media.

\subsection{Definition of Some Terms}

Innovation: Is what leads the work to new assumptions that contribute to pulling the receiver to follow the course of events.

Responsibility and Resolution: One of the important things that must be characterized by the director of the discount, because of the retention of any belongings tarnish and hinder the completion of work.

Fantasy: The director must have a rich imagination and wide horizons, he must imagine and imagine all the minutes and details of the artwork.

Organization: The director as a military commander decides "yes" or "no" in many technical and administrative matters.

Selection: The director's ability to choose from the tasks that must be available in the work of the director.

Hybridization, synthesis and mixing: Of the specifications that must be available in the director the ability to hybridization and the combination and composition between the arts and science, so as to create a new art, the director must be a taste of different sciences.

\subsection{The Problem of the Study}

The problem crystallizes in an attempt to determine to what extent the director's personality can affect television work; through his talent, culture and ability to control. The problem lies in a major question about what role a director's character plays in producing media material.

\subsection{The Questions of the Study}

1. what is TV output?

2. what are the elements of television production?

3. what is the impact of the director's personality in television work?

4. what role does the director play in any television work?

5. what qualifications should a film director have?

\subsection{The Significance of the Study}

The researcher wanted to present the role played by the director and its impact on the television work through the following:

1. His ability to convey feelings and the general psychological atmosphere of feelings.

2. the ability to focus the spectator's attention to the staff.

3. its ability to variables in the scenes such as place and time period or daily time.

4. His ability to highlight the aesthetic potential in the art of photography.

5. The ability to encourage each craft separately so that ultimately can get the best performance for each.

\subsection{Research Goals}

1. To know the effect of the director's personality on the crystallization of aesthetic values.

2. Identify the communicators in terms of education and experience.

3. Explain the role of the director and his relationship with the rest of the team.

4. Disclosure of the concept of professional professionalism in the work of directing.

5. To clarify the role played by the director in directing the programs in a simplified way suitable for all societies.

6. Know the general rules of output and implemented in such a way that the viewer interact with the event (scene).

\section{Methods}

THE researcher used the analytical and descriptive approach (case study) and descriptive statistical methodology for data collection.

\subsection{Research Sources}

Basic sources Books and references. Secondary sources.

\subsection{Definition of Terms}

Impact: It is the measured output from watching television, such as a viewer becoming more aggressive or adopting a certain view. ${ }^{1}$ Personality: Collected characters are human models that carry out dramatic events both inside and outside the frame of the camera. Director: The person responsible for the creative process in converting the text or idea into a final program; in collaboration with a technical staff; as well as authors and editors. ${ }^{2}$ Television work is the main element on which any television station depends; 1-Dar Al-Jil in Beirut, Lebanon 21994 KaramShalaby, Glossary of Media Terms (English, Arabic)

\section{Method}

This study is a kind of descriptive research that aims to portray, analyze and evaluate the characteristics of the contact person and study the current facts and theories in determining the bases and criteria in the success of the process. The study aimed to measure the impact of the director's personality in the production of programs. The writer in the field study followed the following steps:1/ Identify the study community2 / Choose the sample.4 / Data analysis.

\subsection{Data Collection Tools}

This research consists of a random sample of some of the 
workers in Radio and Red Sea Satellite; and some media professionals in the state newspapers (Port Sudan Marinate Baroat -Alfajer Aljadeed). Local newspapers And some media professors at the Faculty of Arts and Humanities.

\subsection{Identifying the Study Community}

The study community is determined by the Red Sea satellite channel and its specialized audience in the field of media and directing work by means of a deliberate sample that aims at this category to produce results that measure the effect of the director in the production process in the period from March to May 2018.

\subsection{Evaluation of the Questionnaire}

After defining the problem and formulating it in the light of the hypotheses and questions that the study seeks to verify, by preparing the topics or themes on which the questions will be based on the knowledge of the cultural and scientific level of the subjects in terms of content in a simple and unambiguous language.

The following form is foreseen: - Some personal data on the level of education, gender, age, specialization, technical field in which he works and practical experience. - Vision of the respondents on the following axes and variables: - Most Satellite TV Watch. - What are the most watched programs and what is the output factor in achieving that gravity.-Axis determines the assessment of the output work according to its elements. - What types of output templates are used in output and program production? - What are the most important elements of the thrill used to attract the viewer? - The extent to which output is aligned with the information and program policy. - The focus of the most important characteristics and specifications of the successful director. Axis shows the role of technology in the development of output. The axis of the role of the director in dealing with the team. Axis deals with the extent of dramatic development in satellite channels. A focus on the problems of television production and output.

\section{Data Analysis}

Table 1. Shows the type.

\begin{tabular}{lll}
\hline Type & Number & Percentage \\
\hline Male & 35 & $70 \%$ \\
Female & 15 & $30 \%$ \\
Total & 50 & $100 \%$ \\
\hline
\end{tabular}

The above table shows that the percentage of males in the research community reached $70 \%$, while the percentage of females was $30 \%$. This indicates that the proportion of male respondents is higher than that of females.

Table 2. Shows the level of education.

\begin{tabular}{lll}
\hline Category & NUMER & The ratio \\
\hline Secondary & 11 & $22 \%$ \\
University & 33 & $66 \%$ \\
Above university & 6 & $12 \%$ \\
Total & 50 & $100 \%$ \\
\hline
\end{tabular}

The above table shows that the percentage of university qualification reached $66 \%$, while the secondary ratio reached $22 \%$, and the university level was $12 \%$. This indicates that the majority of respondents hold university qualifications.

Table 3. Explains specialization.

\begin{tabular}{lll}
\hline Category & Number & Percentage \\
\hline Journalists & 22 & $44 \%$ \\
Academics & 18 & $36 \%$ \\
Technicians & 10 & $20 \%$ \\
Total & 50 & $100 \%$ \\
\hline
\end{tabular}

The above table shows that the proportion of media professionals in the research community reached $44 \%$, while the percentage of academics reached $36 \%$, while technicians reached $20 \%$. This indicates that the majority of respondents are media professionals.

Table 4. Shows practical experiences.

\begin{tabular}{lll}
\hline Category & Number & percentage \\
\hline $3-10$ years & 17 & $34 \%$ \\
$10-20$ years & 12 & $24 \%$ \\
20 and above & 21 & $42 \%$ \\
Total & 50 & $100 \%$ \\
\hline
\end{tabular}

The above table shows that $34 \%$ of the research community has practical experience (3-10 years), while the working experience (10-20 years) is $24 \%$ and $20 \%$ and above $42 \%$. This indicates that the majority of respondents have a wealth of scientific and practical experience.

Table 5. Shows viewers of satellite channels.

\begin{tabular}{lll}
\hline Category & Number & Percentage \\
\hline Yes & 50 & $100 \%$ \\
No & Zero & - \\
Total & 50 & $100 \%$ \\
\hline
\end{tabular}

The table above shows that $100 \%$ of the search community watch satellite channels and that $0 \%$ do not watch them. This indicates that all respondents are watching satellite channels and there is no one who does not watch them.

Table 6. Shows the quality of the most watched channels.

\begin{tabular}{lll}
\hline Category & Number & Percentage \\
\hline General & 30 & $60 \%$ \\
Informational & 10 & $20 \%$ \\
Specialized & 7 & $14 \%$ \\
Total & 50 & $100 \%$ \\
\hline
\end{tabular}

The above table shows that $60 \%$ of the research community watch public channels, $20 \%$ watch news channels, and $14 \%$ watch specialized channels. This indicates that the public channels are the most acceptable among the respondents.

Table 7. Shows the most popular programs.

\begin{tabular}{lll}
\hline Category & Number & Percentage \\
\hline Sports & 10 & $20 \%$ \\
Political & 6 & $12 \%$ \\
Mix & 34 & $68 \%$ \\
Total & 50 & $100 \%$ \\
\hline
\end{tabular}


The above table shows that $68 \%$ of the research community watch various programs, $20 \%$ watch sports programs, and $12 \%$ watch political programs. This indicates that the programs most popular and viewed by the respondents are miscellaneous programs.

Table 8. Shows the assessment of the output work.

\begin{tabular}{lll}
\hline Category & Number & Percentage \\
\hline Excellent & 17 & $34 \%$ \\
Good & 25 & $50 \%$ \\
Weak & 8 & $16 \%$ \\
Total & 50 & $100 \%$ \\
\hline
\end{tabular}

The above table shows that $50 \%$ of the study population believes that the work is good, 34\% think it is excellent and $14 \%$ believe it is weak. This shows that the largest number of respondents believe that output is the main pillar of media work.

Table 9. Shows whether the execution of the director of television work is the main indicator of the success of the media product.

\begin{tabular}{lll}
\hline Category & Number & Percentage \\
\hline I agree & 22 & $44 \%$ \\
Disagree & Zero & - \\
I totally agree & 28 & $56 \%$ \\
Total & 50 & $100 \%$ \\
\hline
\end{tabular}

The table above shows that the percentage of respondents who agree is $44 \%$, while those who strongly agree $(56 \%)$ and those who disagree $(0 \%)$. This indicates that the majority of respondents see the work of the director as the main indicator of the success of the media item.

Table 10. Shows the most important qualities that should be available in the director.

\begin{tabular}{|c|c|c|}
\hline Category & Number & percentage \\
\hline $\begin{array}{l}\text { Innovation } \\
\text { decisiveness }\end{array}$ & Zero & - \\
\hline Fantasy and selection & Zero & - \\
\hline All that is true & 50 & $100 \%$ \\
\hline Total & 50 & $100 \%$ \\
\hline
\end{tabular}

The table above shows that $100 \%$ of the study community believes that the directorate should be comprehensive.

Table 11. Shows whether preparing the technical vision and turning it into a scenario is one of the most important components of the work of directing.

\begin{tabular}{lll}
\hline Category & Number & percentage \\
\hline I agree & 32 & $64 \%$ \\
Disagree & 4 & $8 \%$ \\
I totally agree & 14 & $28 \%$ \\
Total & 50 & $100 \%$ \\
\hline
\end{tabular}

The above table shows that the percentage of respondents who agree is $64 \%$, while those who strongly agree $28 \%$, either disagree $8 \%$. This indicates that the majority of the respondents believe that the work of directing is the basis of the information process.
Table 12. Shows the output product of the Sudanese satellite compared to other satellite channels.

\begin{tabular}{lll}
\hline Category & Number & percentage \\
\hline I agree & 22 & $44 \%$ \\
Disagree & 10 & $20 \%$ \\
I totally agree & 18 & $36 \%$ \\
Total & 50 & $100 \%$ \\
\hline
\end{tabular}

From the above table it is clear that $44 \%$ of the respondents agree, while $36 \%$ strongly agree, and $20 \%$ disagree. This indicates the output product of Sudanese satellite channels is weak and needs to keep pace with the developments in the media.

Table 13. Illustrates the dramatic development in the Sudanese satellite compared to other templates.

\begin{tabular}{lll}
\hline Category & Number & percentage \\
\hline I agree & 15 & $30 \%$ \\
Disagree & 30 & $60 \%$ \\
I totally agree & 5 & $10 \%$ \\
Total & 50 & $100 \%$ \\
\hline
\end{tabular}

From the above table it is clear that the percentage of respondents who disagree is $60 \%$, while the approvers are $30 \%$, while those who strongly agree are $10 \%$. This indicates that the majority of the respondents believe that the Sudanese drama needs further refinement and development.

Table 14. Illustrates the director's use of persuasion to influence the audience.

\begin{tabular}{lll}
\hline Category & Number & percentage \\
\hline I agree & 37 & $73 \%$ \\
Disagree & Zero & - \\
I totally agree & 13 & $26 \%$ \\
Total & 50 & $100 \%$ \\
\hline
\end{tabular}

From the above table it is clear that the percentage of respondents who agree is $73 \%$, while those who strongly agree $(26 \%)$ and those who disagree $(0 \%)$. This shows that the majority of respondents believe that the director needs a lot of diligence to convince the viewer.

\section{Results}

1. The study came out that the character of the director has the greatest impact on the success of any media message.

2. The study also found that the elements of suspense and surprise create a strong impact in gaining the attention of viewers.

3. The study also revealed that directing science depends on the technical talent and the ability to keep pace with self-development.

4. The work of directing is the basis of the information process and the effort of the team depends on completion.

5. Output talent is refined by the academic side.

6. The art of directing a self-standing science depends on the personality of the output and the type of material produced. 
7. The director needs a lot of diligence to convince the viewer.

8. One of the most important qualities that characterize the successful director is creativity - firmness - imagination - the possession of organizational skills to work - enjoy diplomacy and patience and bear the pressure of work.

\subsection{Findings}

1. There are no specialized directors in the field of work and art.

2. The lack of technical equipment to match the technical development.

3. The absence of freedom in media work affects the output under the totalitarian regimes.

4. Lack of a good training component supports the presence of human cadre who possesses talent.

\subsection{Conclusion and Recommendation}

In this research, we mentioned the director's personality in the production of television work in detail in order to clarify the director's tasks and highlight the effort he is making to win public confidence.

It is also clear to us through the research that the work of the director is a painting is not completed unless mixed with many colors, so he needs a professional staff to highlight his ideas.

The researcher also noted through the research that the output is an important part of the management of any media organization and clarified, which leaves no room for doubt that the character of the director has the greatest impact on the success of any media material.

The supreme goal of the director's character is to reconcile the views of the entire working group with the production of the media material. here are the results:

1. the director must be comprehensive and briefed on all sections of television work and inspiration to the working group and put forward ideas.

2. Restructuring of the administrative staff through the classification of directors and the adoption of the principle of efficiency in directing the distribution of television programs.

3. the director needs to innovate and get out of the stereotype.

4. The director must be able to test the appropriate scene positions or design the site himself.

5. the director must be acquainted with the permanent exploration in his field, and training and provide the possibilities and the environment to be able to be creative.

6. The Sudanese director should keep pace with the developments in the media, and work on the personal character of the work of directing and continuing training and not only the studies.

7. it is necessary to separate the television, radio and press output to acquire each director's special characteristic in his field of specialization.

8. Work to raise the capacity of technical staff and training in the latest techniques of digital technology.

9. Promotion of media messages in form and content in line with the revolution of the work of output.

\section{References}

[1] Abdel Khalig Mohamed Ali (2010). Radio and Television Production, Beirut Dar Al-Mahja Al-Bayda.

[2] Al Amin Abdul Rahman (2014) Director of Sudanese Television published study.

[3] Abdul MajidShukri (1995) Communication Technology (Radio and Television Production).

[4] Atef Adly (2008) Cultivation process journal of broadcasting and electronic Cairo.

[5] Ashraf Al-Muhanna (2009) Arab space and variables of the age, University Knowledge House.

[6] KaramShalabi: Television Production and Production Arts, Cairo. Islamic Heritage Library 2000.

[7] Mohamed Saad Ahmed Ibrahim - Recent trends in the study of contact - published study 2000 .

[8] Mohammad Mirat, the contact person in the UAE Published study (2006) Publishing electronic newspapers on the Internet.

[9] Said El - Qadin El - Naga The Egyptian Egyptian House Cairo, Egypt The super-text of unlimited e-output in space and time has been added via user paths 2014 .

[10] Schram w / psycho log icalprosses under lying cultivation effects further test of construct accessibility human communication research Vol 22no1996 Media and Technology of Transmitters. 